\title{
Recycling of fresh concrete exceeding and wash water in concrete mixing plants
}

\author{
J.A. Férriz-Papi ${ }^{\mathrm{a} \bowtie}$ \\ a. Universidad de Alicante. (Alicante, España) \\ \jaferrizp@gmail.com
}

Received 2 January 2013

Accepted 20 September 2013

Available on line 27 September 2013

\begin{abstract}
The exceeding concrete and washing equipment water are a matter to solve in concrete production. This paper explains several possibilities for recycling and analyses the products obtained with one recycling equipment. The objective of this work is to study the possibility to increase the percentage of recycling in new mixes. The developed study relates wash water density and fine particles content. Besides, mortar and concrete samples were tested introducing different quantities of these fine particles, substituting cement, sand or only as an addition. Consistency, compressive strength, setting time, absorption, and capillarity were tested. The results indicated an improvement of the studied properties in some percentages when substituting sand. It confirms the possibility to introduce larger quantities of wash water in new concrete mixes, with corrections in sand quantity depending on water density.
\end{abstract}

KEYWORDS: Concrete; Fresh concrete; Waste treatment; Superplasticizers; Finess

Citation/Citar como: Férriz-Papi, J.A. (2014) Recycling of fresh concrete exceeding and wash water in concrete mixing plants. Mater. Construcc. 64 [313], e004 http://dx.doi.org/10.3989/mc.2013.00113

RESUMEN: Reciclado de sobrantes de hormigón fresco y agua de lavado en plantas de hormigón. Los hormigones frescos sobrantes y aguas procedentes de la limpieza de equipos son un inconveniente a resolver en las plantas de hormigón. Este artículo explica varias posibilidades de reciclado y analiza los productos obtenidos en un equipo reciclador concreto, con el objetivo de estudiar el incremento del porcentaje de reciclaje en nuevas amasadas. El estudio realizado relaciona la densidad del agua de lavado y el contenido de partículas finas. Además, ensaya muestras de mortero y hormigón realizando sustituciones de estas partículas finas por cemento, arena o simplemente como adición. Determina consistencia, resistencia a compresión, principio y fin de fraguado, absorción y capilaridad. Los resultados indicaron un incremento general de las propiedades estudiadas en algunos porcentajes de sustitución por arena. Ello confirma la posibilidad de introducir mayores cantidades de agua de lavado en nuevas amasadas de hormigón, mediante correcciones en la dosificación de arena en función de la densidad del agua.

PALABRAS CLAVE: Hormigón; Hormigón fresco; Tratamiento de residuos; Superplastificantes; Finura

Copyright: (C) 2014 CSIC. This is an open-access article distributed under the terms of the Creative Commons Attribution-Non Commercial (by-nc) Spain 3.0 License.

\section{INTRODUCTION}

The concrete mixing plant generates different solid waste, fresh concrete residue or in water suspension, during the production process of concrete mixes. This waste mainly comes from fresh concrete exceeding and equipment washing. Concrete waste comes from exceeding mixes, rejections due to deficient supply, testing mixes, etc. Besides, water consumption is very high in these installations. Equipment and machinery washing can reach to over $30 \%$ of the total water consumption (1). 
The disposal of this waste brings to many drawbacks that must be solved inside the mixing plant. Firstly, it is a considerable cost in raw materials and water. Moreover, it leads to waste management, which must be stored in the mixing plant until it is hardened. Then, it must be broken into small pieces, loaded, transported and dumped. Hardened concrete is not dangerous, but in the case this waste was dumped as fresh concrete, it could damage soil and water that were in contact with, as it would be liquid substance with large basicity because of the cement and, besides, the large fine solids content.

These drawbacks, which increase with the growing environmental regulation and water scarcity, are bringing to the interest in valuation and recovery. In Spain, systems for water efficiency have been implemented by decanting processes of the water used. More recently, other recovery systems are being introduced, which get higher levels of recovery of the suspended solid part. The regulation for waste management in Spain, presented in Law 22/2011, of waste and polluted soil, obliges to control dumping for this waste. Besides, the regulation EHE-08 establishes the possibility of introducing wash water in new mixes for the first time. So, the quantity of this water is limited in Art. 27 to a density below $1.3 \mathrm{~g} / \mathrm{cm}^{3}$, and never over $1.1 \mathrm{~g} / \mathrm{cm}^{3}$ in the total mixing water. Besides, Art. 31.1 limits the total fines content in concrete mixes to $185 \mathrm{~kg} / \mathrm{m}^{3}(2)$.

With these limits, the analysis of the treatment systems used is essential to know the possibilities for recycling more widely. In the present work, the study of a real case allows the analysis of the obtained products and their performance inside of new concrete mixes, which can show the possibility to optimize the process. The methodology used and the results obtained show new possibilities to the study of this waste and the use as water and raw materials for new mixes, as well as the best proportions to increase the quantity of recycled products without any significant variation in the concrete properties.

\subsection{Recycling systems}

There are several possibilities of treatment for this waste. Mechanical or chemical systems can be used. These last ones are with the use of additives.

\subsubsection{Recycling by mechanical systems}

In these processes, it is made a separation of materials and water from exceeding mixes and truck washing according to the solids size. Different treatments can be implemented together, and different products are obtained in each process.

The first treatment separates thickest aggregates from the rest. In this way, two products are obtained: recovered aggregates and wash water (3):
- The recovered aggregates are very similar to the original ones, but with important scarcity of the thinnest part, as a cleaning process has been carried out. The use is limited to low relevant concrete, although the quality of this product can be improved with an adequate addition of sand and fine particles.

- The wash water contains the rest of elements: water, cement and the thinnest part of the aggregates. It can be used as cleaning water for other equipment, but it has to be considered that a white thin film will be left after the cleaning process, and it must be apart from the contact with human skin. It is also possible to be used as mixing water, but with the consideration of the quantity of fines that are introduced in the concrete mix, what will affect the characteristics of the final product. In this case, the characteristics with this product are necessary to be studied.

These treatments are the most known. As it can be observed, the recovery of these products is possible to be developed with the introduction in new mixes, but before that, the adequate proportions and possible corrections must be studied in order not to affect significantly the characteristics of concrete. Some research has been developed about it and it confirms this possibility, but it is necessary to study every particular case so as to achieve an optimal system performance.

The wash water can have a second treatment, which is a separation of suspended solids. So, two new products are obtained: clear water and slurry:

- The clear water consists of water without any suspended solids, where ions have been generated from materials and compounds due to the contact with cement, and it produces an increase of basicity. This product can be used as cleaning water for equipment, with some specific conditions. About the introduction in new mixes, it can be used whenever its composition and performance is known.

- The slurry comprises the solid part that is separated from wash water. This is the most problematic product. The high content of fine solid elements deeply affects the use in new concrete mixes. So, it can be recycled or it must be made in very small proportions, and it is not good for equipment cleaning either. It is usually compressed and the existing water is extracted, or it is simply left until drying. Then, it is grinded and dumped.

\subsubsection{Recycling by chemical systems}

These systems are based on the addition of super-plasticisers $(4,5)$. It consists of the addition of a stabilizing additive which gets the cement stop hydration (or hydrate more slowly). When this concrete exceeding is going to be used, an activating additive is added, and the hydration process is 
activated again. It is established that not more than one or two cubic meters per mix can be activated, and this way, new concrete is mixed with it.

The period of time to stop concrete setting depends on the quantity of stabilizer added. The additive producer makes reference Tables where the doses needed are shown according to the time and concrete volume to stabilize. The quantity of activator, which is usually a setting accelerator, depends on the stabilizer added, besides the volume and time needed for the setting time.

They can be used for concrete exceeding, as well as waste water from concrete mixer truck washing. In the first case, the stabilizer is added to the mix, and it is left until this mix is used for new concrete. In the second case, much less water than usually is used for the truck washing and the additive is included in this water to be combined to the waste, and so it makes contact with the whole surface inside the mixer. This way, hydration is stopped until the moment to be used in new mixes, in which the inside water will be sustracted in order to be used as mixing water.

This chemical systems need specialist staff and responsible of the work in the concrete mixing plant. In addition, the use of additives increases the cost of the process.

\section{EXPERIMENTAL}

\subsection{Study of a real case}

This study was based on the analysis of a mechanical recycling system that was already operating. The main objective was to improve the system and to study the possibility of recycling of the obtained products: wash water and recovered aggregates. It was to prove the possibility of increasing the quantities of these products to be introduced in new concrete mixes, as in that moment, the proportions were very little to avoid any affection to the characteristics of new concrete.

The recycling equipment was in a concrete mixing plant of Hormigones del Vinalopó S.A. in Alicante. The company that installed this equipment was Frumecar S.L. The basis for the equipment work was the waste washing when it was pulled and raised by a screw-type conveyor. The waste input was made through a hopper that directed it to this conveyor.

When the waste reached to the screw-type conveyor, its turn obliged it to go up. At a certain height of this way, a water input was activated. This water generated a flow on the opposite direction of the waste flow, and it caused the dragging of the finest solid particles. This dragging process was helped by some holes in the screw, until the final product got the highest point, when it is thrown to a place prepared for it.
Water and dragged solid particles, which formed the wash water, was directed to underground tanks. Inside of them, there were agitators which maintained the fine solid particles in suspension until the introduction of the wash water in new mixes. The use of this wash water was made by two different systems, with their corresponding pumping systems. The first one was used for the recycling process by the recirculation of wash water towards the water input screw-type conveyor, the hopper, or the introduction in new concrete mixing trucks for washing. The second one was used for the introduction in new concrete mixes, as it was directed to the weighing scales of the mixing plant, in order to mix wash water and clean water, and to obtain the mixing water. At the same time, the recuperated aggregates were stored until their use in lean concrete and bases.

The control of the wash water was carried out with the density measurement. The operator of the plant had a Table that let him know the quantity of clean water and wash water to be added depending on this density. The maximum density of wash water for use was established in $1.2 \mathrm{~g} / \mathrm{cm}^{3}$. If this density was over it, the wash water was extracted and dumped, as the agitators in the tanks could not work properly. The introduction of wash water in new concrete mixes was very small; it was never over $2-3 \%$ of cement weight in the mix, that is, about $5 \%$ of the total water. It resulted in an average density for mixing water of less than $1.01 \mathrm{~g} / \mathrm{cm}^{3}$. There was not any other change in the concrete mix, apart from the water substituted by wash water in the system. These proportions were very small, so as to avoid any reduction in the properties of the new concrete. But it was a much reduced proportion and, subsequently, the system was underused.

\subsection{Methodology}

The planning of the testing process was developed starting with the information obtained from other similar studies about the products obtained in different mechanical systems for recycling. F. Sandrolini (3) studied different proportions of wash water in new concrete mixes, testing the variation in several of their physical and mechanical properties. N. Su (6) made tests with different kinds of water used in new mixes: clean water, underground water and wash water. The changes of properties in mortars and concrete were studied. In another study, B. Chatveera (7) analysed the content of wash water, with the substitution of normal water between 0 and $100 \%$ and studying the introduction of solids in new mixes. At the same time, changes about the ratio water/cement were made. In this way, different properties and their variation were studied depending on the proportions of wash water used. 
The properties studied in these studies were observed and the development of this study was planned with the products obtained in this system and the analysis of different recycling proportions of wash water. The possibilities were checked according to the available resources in the laboratory as well as in the mixing plant site. So, four stages were differentiated: the first one based on the fieldwork at the mixing plant, and the rest at the laboratory.

The fieldwork (first stage) was used for contacting with the recycling system and how it worked. The convenient way for the obtaining of product samples was established: from the stock of recovered aggregates and the wash water tanks. A calendar was planned for the study of variation in density and $\mathrm{pH}$ of wash water during the working day in 7 sporadic days in a month's time. Finally, a census of truck washing was elaborated, where the approximate volume of waste and the time used was noted down.

The second stage was completely developed at the laboratory. It started with testing the obtained products. 7 samples of wash water that were extracted from the tanks, with different density controlled with a densimeter in the workplace, were taken into laboratory, weighed and dried at $110{ }^{\circ} \mathrm{C}$ up to constant weight. So, the weight of the solid part of the wash water was obtained $(3,7)$. The results were represented in a chart where a relationship was established between the parameters of density and percentage of the solid part (dried slurry) of the wash water, and the theoretical tendency line was calculated (Figure 1). This chart allowed the third stage planning.

Besides, 6 samples of recovered aggregates were studied. The analysis was based on the variations that could appear in the aggregates size as a reduction of the smallest part was supposed (1). The graduation was analyzed according to UNE-EN 933-1:2012 (8), fines content and sand equivalent according to UNE-EN 933-8:2012 (9). The graduation was studied with the basic series of sieves shown in Table 28.3.b of the Spanish Regulation for structural concrete EHE (2). This part was completed with the moisture percentage of the aggregates in the stock.

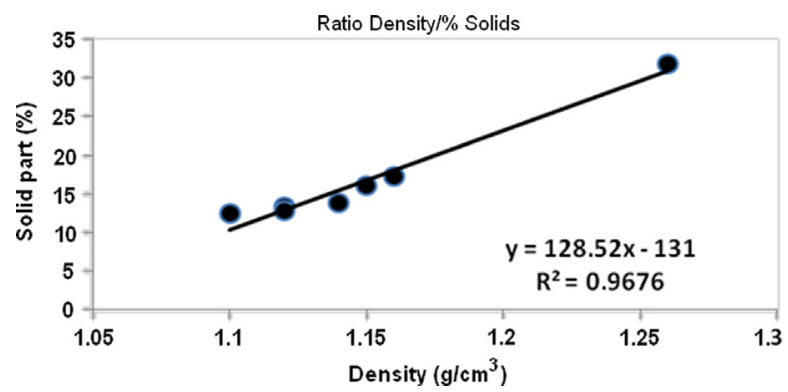

Figure 1. Theoretical line tendency that established the relationship between density and percentage of the solid part of the wash water.
The third stage consisted of the study of the variation of characteristics in mortars with different addition quantities of wash water $(3,7)$. With the impossibility to test wash water directly in the laboratory in the adequate conditions, the extraction of the solid part was made by drying processes, with the obtaining of dried slurry. Later, it was ground and introduced in the different mixes, according to the proportions to study.

A mortar reference sample was made, with $450 \mathrm{~g}$ of cement CEM II/A-L $32.5 \mathrm{R}, 1,350 \mathrm{~g}$ of limestone sand and $250 \mathrm{~g}$ of water. The limestone sand used in these samples was the same as the original aggregates of the recovered ones. It was sifted and selected according to CEN standardization in order to avoid any dispersion in the results.

From the quantities of this reference sample, the proportions of dried slurry were established in 5, 10, 15,20 y $25 \%$ respect to cement weight. This way, density of wash water was supposed to be studied between 1.08 and $1.26 \mathrm{~g} / \mathrm{cm}^{3}$ (Table 1). These percentages were implemented in four different groups, with the following changes:

Group 1. To add dried slurry to the reference sample

Group 2. To substitute cement for dried slurry (in weight)

Group 3. To substitute sand for dried slurry (in weight)

Group 4. To add dried slurry and to increase proportionally the ratio water/cement with the addition of $3.2 \mathrm{~g}$ of water per every $5 \%$ of dried slurry added. A different reference sample was made with $255 \mathrm{~g}$ of water, and all the mortar samples in this group were made from this initial water quantity (10).

A mortar sample was made with clear water. This water was obtained by settling a wash water sample in laboratory. The quantity of clear water used was $255 \mathrm{~g}$, as the second mortar reference sample.

The testing program resulted in 23 different mortar mixes, and 3 sample mixes were made in laboratory for each one. All these mortar mixes were tested to compressive strength according to UNE-EN 196-1:2005 (11), absorption by immersion in water, absorption per capillarity according to UNE-EN 1015-18 (12), consistency according to UNE-EN 1015-3:2000/A2:2007 (13) and setting time according to UNE EN 196-3:2005+A1:2009 (14).

TABle 1. Quantities of addition of dried slurry

\begin{tabular}{cccc}
\hline $\begin{array}{c}\text { \% Dried } \\
\text { slurry }\end{array}$ & $\begin{array}{c}\text { Solids } \\
\text { quantity (g) }\end{array}$ & $\begin{array}{c}\text { \% of fines in } \\
\text { water }\end{array}$ & $\begin{array}{c}\text { Estimated density } \\
\text { (g/cm3) }\end{array}$ \\
\hline 5 & 22.5 & 8.26 & 1.08 \\
10 & 45.0 & 15.25 & 1.14 \\
15 & 67.5 & 21.26 & 1.18 \\
20 & 90.0 & 26.47 & 1.23 \\
25 & 112.5 & 31.03 & 1.26 \\
\hline
\end{tabular}


The test of absorption by immersion was made in two stages. Firstly, 3 mortar samples per mortar mix were dried in the oven at $110{ }^{\circ} \mathrm{C}$ and then they were weighted. Secondly, they were immersed in water during 24 hours until saturation and they were weighted again. About the test of capillarity absorption, it was developed by immersing the samples $5 \mathrm{~mm}$ in water by the smallest face. The samples were weighted by the time, and the height of water reached in each vertical face was noted down. Data were got at 5, 10, 15 y 30 minutes and at 1, 2, 3, 4 and 8 hours from the starting time of the test.

The fourth and last stage consisted of concrete samples testing. These tests were exclusively dedicated to confirm the results obtained with mortars. 4 different mixes were programmed: one reference sample and three others to substitute sand for an equal weight of dried slurry, with the proportions of 10,15 and $20 \%$ respect to cement weight (Table 2).

In these concrete mixes, consistency was reduced due to the increase of fines with the addition of dried slurry, and it damaged the elaboration process. For this reason, the ratio water/cement was progressively increased. The tests made on these mixes were consistency according to UNE-EN 123502:2009 (15) and compressive strength according to UNE-EN 12390-3:2009/AC:2011 (16).

As the results to obtain only needed to be comparable between them, cylindrical samples of $8.5 \mathrm{~cm}$ diameter and $17 \mathrm{~cm}$. height were made for the compressive strength test. This made easier their handling and allowed using the available sources in laboratory.

\section{RESULTS AND DISCUSSION}

\subsection{The recovered aggregates}

The results obtained can be observed in Table 3 and Figure 2.

In general, the recovered aggregates were the same as the original ones in the concrete production process, but the main difference was that they had had the finest part eliminated.

TABLE 2. Quantities for each concrete mix studied

\begin{tabular}{|c|c|c|c|c|}
\hline Material & $\begin{array}{c}\text { Reference } \\
\text { sample } \\
\text { (Kg) }\end{array}$ & $\begin{array}{c}10 \% \\
\text { slurry } \\
(\mathrm{Kg})\end{array}$ & $\begin{array}{c}15 \% \\
\text { slurry } \\
(\mathrm{Kg})\end{array}$ & $\begin{array}{c}20 \% \\
\text { slurry } \\
\text { (Kg) }\end{array}$ \\
\hline CEM I 42,5 R & 4.701 & 4.701 & 4.701 & 4.701 \\
\hline Water & 3.597 & 3.592 & 3.653 & 3.728 \\
\hline Slurry & 0.000 & 0.470 & 0.705 & 0.940 \\
\hline Sand $0-4$ & 18.636 & 18.163 & 17.927 & 17.601 \\
\hline Gravel 1 & 3.886 & 3.886 & 3.886 & 3.886 \\
\hline Gravel 2 & 6.476 & 6.476 & 6.476 & 6.476 \\
\hline
\end{tabular}

In the test about samples of these products, it was observed that the granulometric curve was similar to the theoretical curve of Füller in many cases. The most different ones corresponded to the days in which the mixing plant was producing much more mortar than concrete, and the sand content was higher.

The most relevant variation that was appreciated was the lack of fine elements, as the washing process had carried them out (Figure 2). The fines content test also showed this lack. The short proportion that passed 0.063 sieve was mainly cement particles. It seemed that they had been adhered to coarse aggregates, and when they were dried and sieved, these particles were separated. It was observed by the grey colour of the material that was retained in these sieves. It also made us think that other cement particles could still be adhered to the aggregates surface.

Humidity percentage grew considerably, and it mainly changed depending on the time of the sample extraction. It was bigger in the early morning.

Finally, the results for the sand equivalent were over 70, even 75 in some cases. It indicated that the quantity of clay was reduced, and these aggregates can be used in new concrete mixes, with the considerations established according to Article 28.4.2 of EHE-08 regulation (2). The aggregates washing in the recycling process probably reduced this clay contents, and then it formed part of the wash water.

\subsection{The wash water}

It was generally observed that a reduction in compressive strength was produced with the addition of dried slurry. The results in longer ages, mainly at 90 days, resulted in very similar curves to 28 days or even shorter. Figure 3 shows the compressive strength comparison at 28 days.

The addition of dried slurry at $5 \%$ with no other change in the mix resulted in an increase of compressive strength, as it was over the reference sample. The same thing did not happen with the rest in this group, as strength decreased considerably. In the case of cement substitution, a general strength reduction was produced, which was shown in a straight tendency line. The sand substitution produced a small decrease with $5 \%$ of dried slurry

TABLE 3. Results of tests with recovered aggregates

\begin{tabular}{lcccc}
\hline $\begin{array}{l}\text { Recovered } \\
\text { aggregates }\end{array}$ & $\begin{array}{c}\text { Humidity } \\
(\mathbf{\%})\end{array}$ & $\begin{array}{c}\text { Granulometric } \\
\text { modulus }\end{array}$ & $\begin{array}{c}\text { Fines } \\
(\%)\end{array}$ & $\begin{array}{c}\text { Sand } \\
\text { Equivalent }\end{array}$ \\
\hline $17-2$ & 7.74 & 5.06 & 4.33 & 72.8 \\
$20-2$ & 9.87 & 4.77 & 2.98 & 70.8 \\
$25-2$ & 9.62 & 4.93 & 3.57 & 77.5 \\
$28-2$ & 16.09 & 3.18 & 4.00 & 76.4 \\
$3-3$ & - & 3.94 & 2.50 & - \\
$2-4$ & 9.85 & 5.08 & 7.12 & - \\
\hline
\end{tabular}




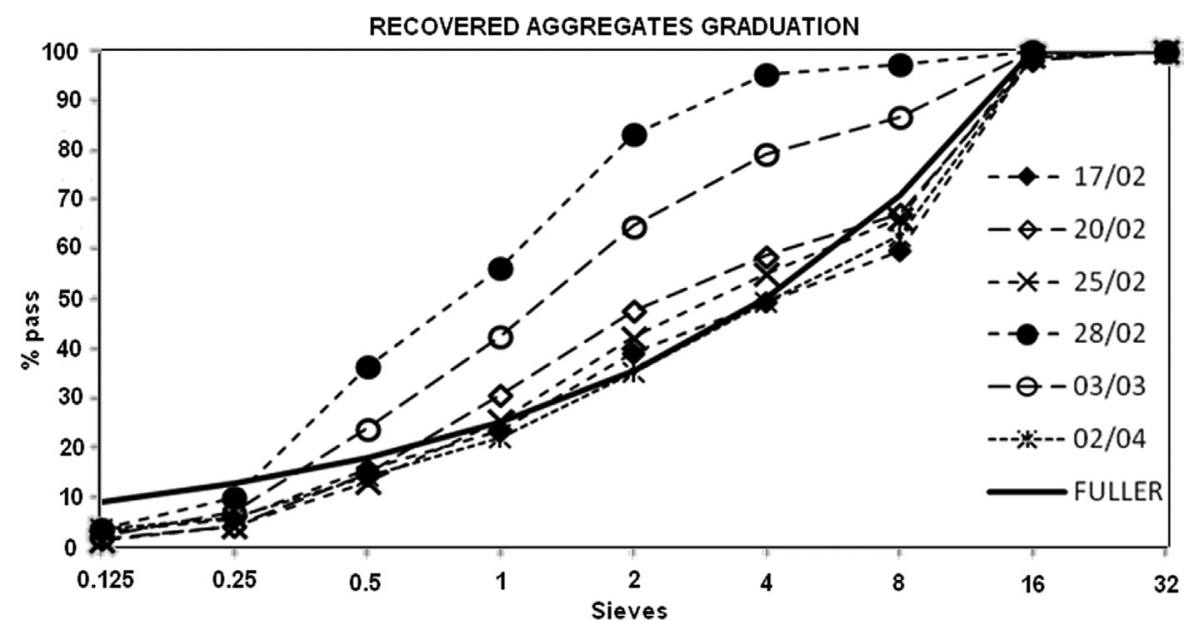

FIGURE 2. Graduation study of the recovered aggregates tested, compared to the theoretical curve of Füller.

addition. But, on the contrary, an increase occurred in the following mixes, which got the maximum results with the $15 \%$. From this point, the compressive strength tendency curve decreased again (Figure 3). The fourth group, the addition of dried slurry with an increase of the ratio water/cement, the curve tendency was decreasing progressively, although it was not much steep.

The mortar samples tested generally tended towards the improvement of water absorption with the increase of dried slurry addition. The shortest absorption was obtained in the group of the substitution of sand with dried slurry. In some cases, it was even shorter than the reference sample. The increase of absorption in the case of the only addition of slurry was very large, mainly in the samples with the largest additions of slurry (Figure 4).
Density of mortar samples tended towards reduction except in the group of sand substitution. In this group, the results of density had a small increase (Figure 5). If compressive strength and density are compared, it can be observed that both properties had a similar tendency.

It was generally observed that an increase of capillarity absorption occurred with the slurry content (Figure 6). It occurred in the group of sand substitution and also when the slurry was introduced as an addition and the ratio water/cement was increased. The results were very similar to the reference sample; even some of them were shorter. The group with the only addition of dried slurry suffered from a considerable increase of capillarity.

The consistency test concluded that the more slurry quantity added the more water quantity needed,

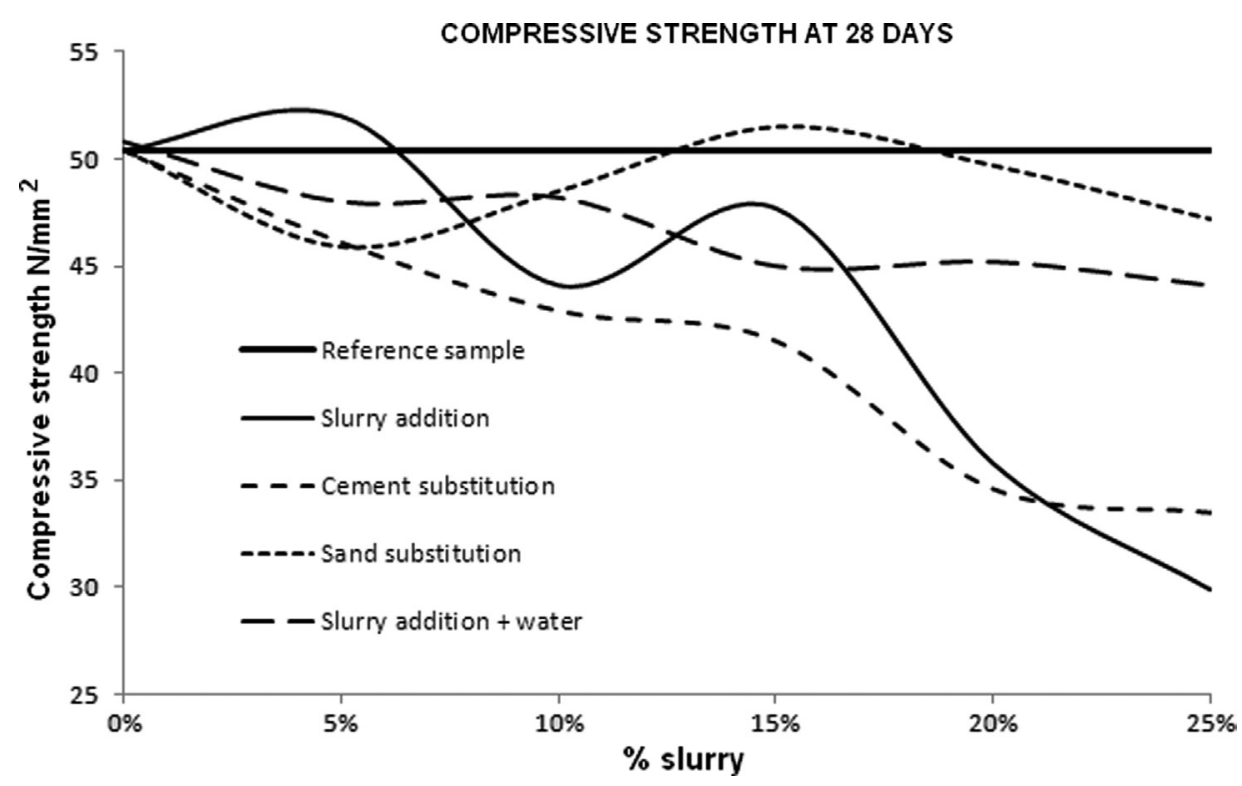

Figure 3. Comparison of tendency curves of compressive strength at 28 days. 


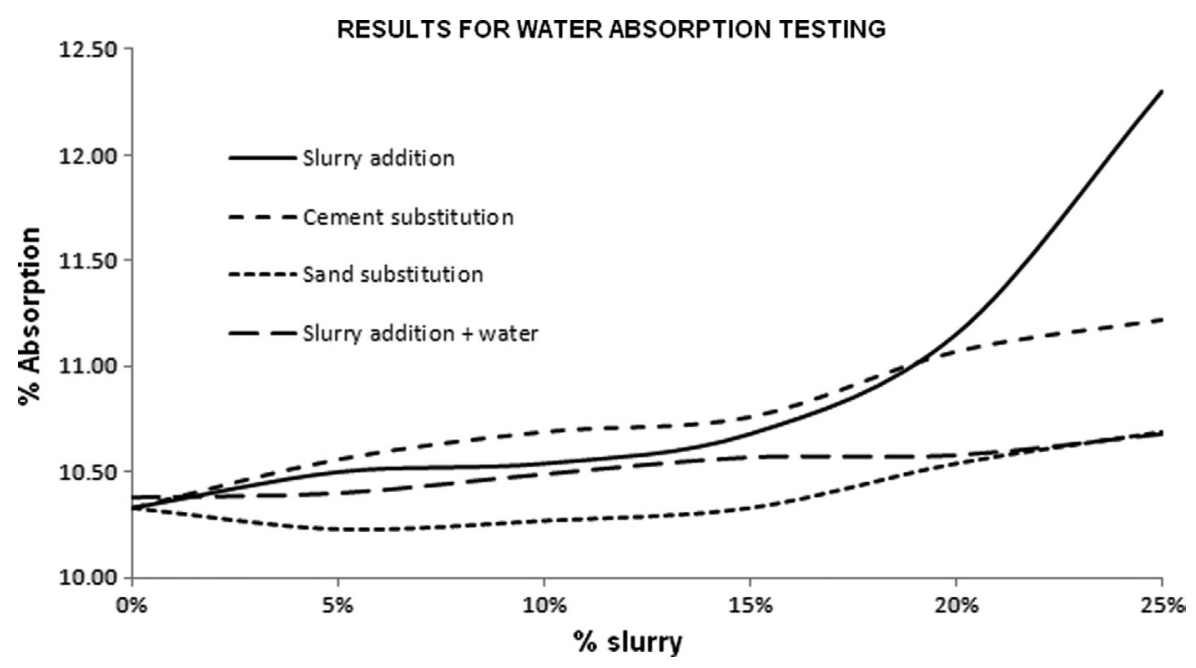

FIgURE 4. Water absorption in the different mortar samples.

which produced a reduction of workability. The group of slurry addition was the most notorious. The samples with the largest quantities of slurry were the most difficult ones to mix due to the lack of plasticity (Figure 7).

In some cases, it was observed that a small increase of consistency was produced, but it was reduced in the following mixes. It may have been produced by the contribution of fines particles to plasticity in the mix. In the group of cement substitution, a reduction of consistency was observed, but not as notorious as in the rest. In the group of slurry addition and increase of water proportion, a reduction of consistency was also observed, despite the water proportion increase. But this reduction was much more reduced than in the other groups, with a descent line tendency. If the results in the tests of consistency and compressive strength are compared (Figure 7), a very similar tendency is observed, as it happened to density.

About setting time testing, the setting time for the group of only slurry addition seemed to be longer instead of reducing, but in the last mix it was reduced considerably. In the groups of cement or sand substitution, the setting time was reduced; sometimes it was even less than one hour. It did not happen the same in the group of slurry addition and increase of water proportion, in which the setting time was almost the same.

Generally, the addition of dried slurry increased the percentage of fine particles. This circumstance brought to different results according to the variation of other components in the mix. The increase of compressive strength can be due to the increase of the compactness of the hardened mortar and the reduction of the capillarity net as a consequence of the

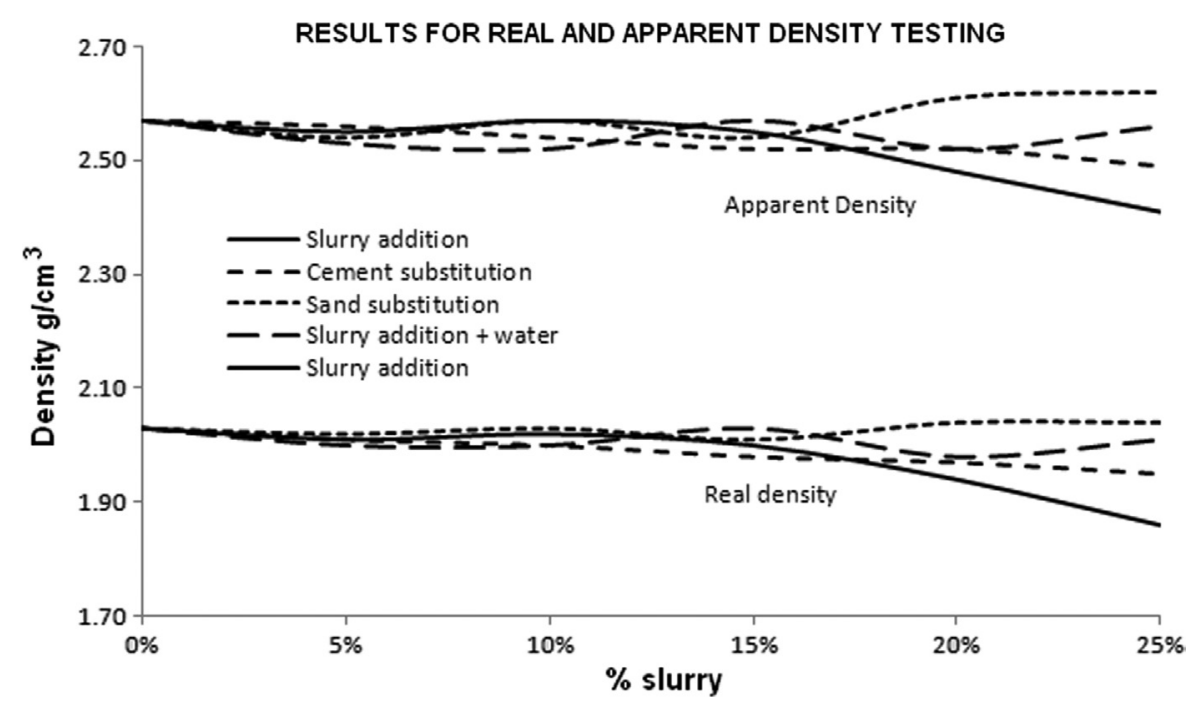

FIGURE 5. Apparent and real density in the different mortar samples. 


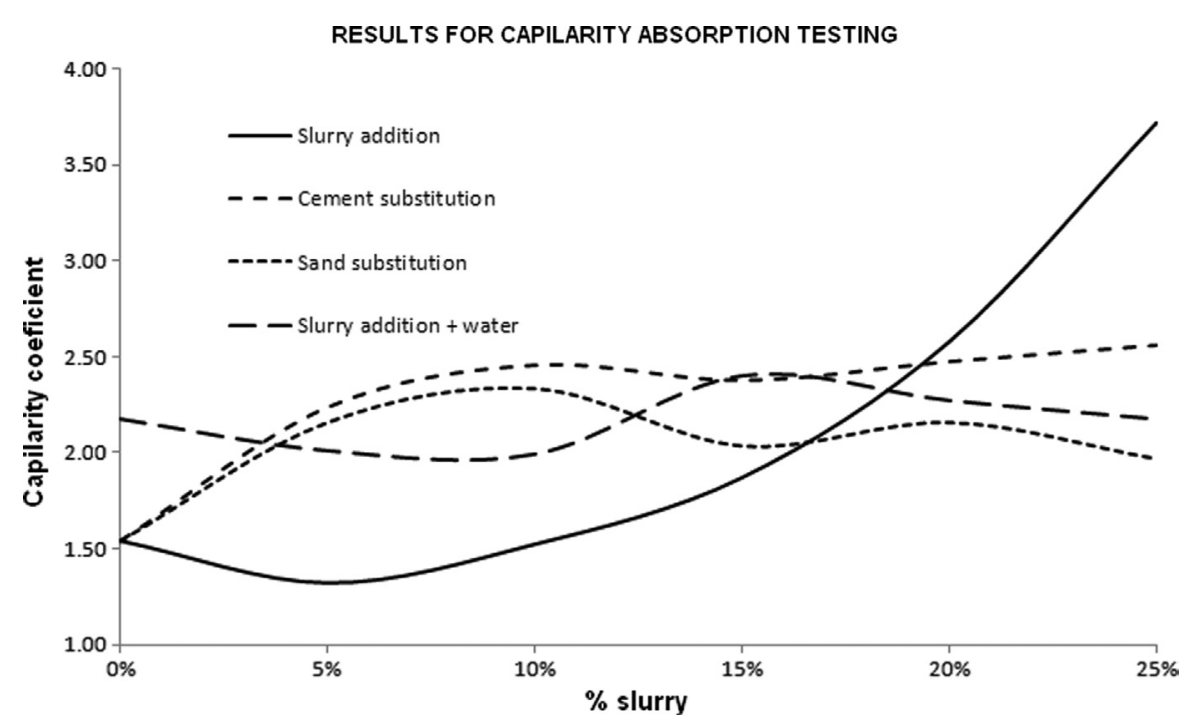

FIGURE 6. Results of the capillarity absorption tests.

increase of fines with the addition of the slurry (3). Despite that, the reduction of consistency also reduced workability. It could have affected to the samples process of making and therefore, to the resulting characteristics. In these cases, the implementation of super-plasticizers could have been a solution (17), but this question was not tested in this study.

It must be noticed that this slurry was not inert. Some parts corresponded to cement that, in an indefinite proportion, was to hydrate. This cement could have contributed in some ways to the increase of strength, as well as to the consolidation and compactness of the mass $(18,19)$.

Finally, any significant variation was not appreciated in the mortar sample with clear water. The obtained results were very similar to the reference sample.

The results in mortars were tested with concrete samples. The mixes with the best characteristics corresponded to sand substitution in the percentages from 10 to $20 \%$. These results defined the concrete samples testing with these proportions. They were tested and the results in compressive strength were very similar. The variation of the results according to the reference sample was less than $5 \%$. The reduction of compressive strength was never over $3 \%$. It confirmed the results with mortars, and concluded that these corrections in the sand proportion are right for the use of wash water in new concrete mixes (Table 4).

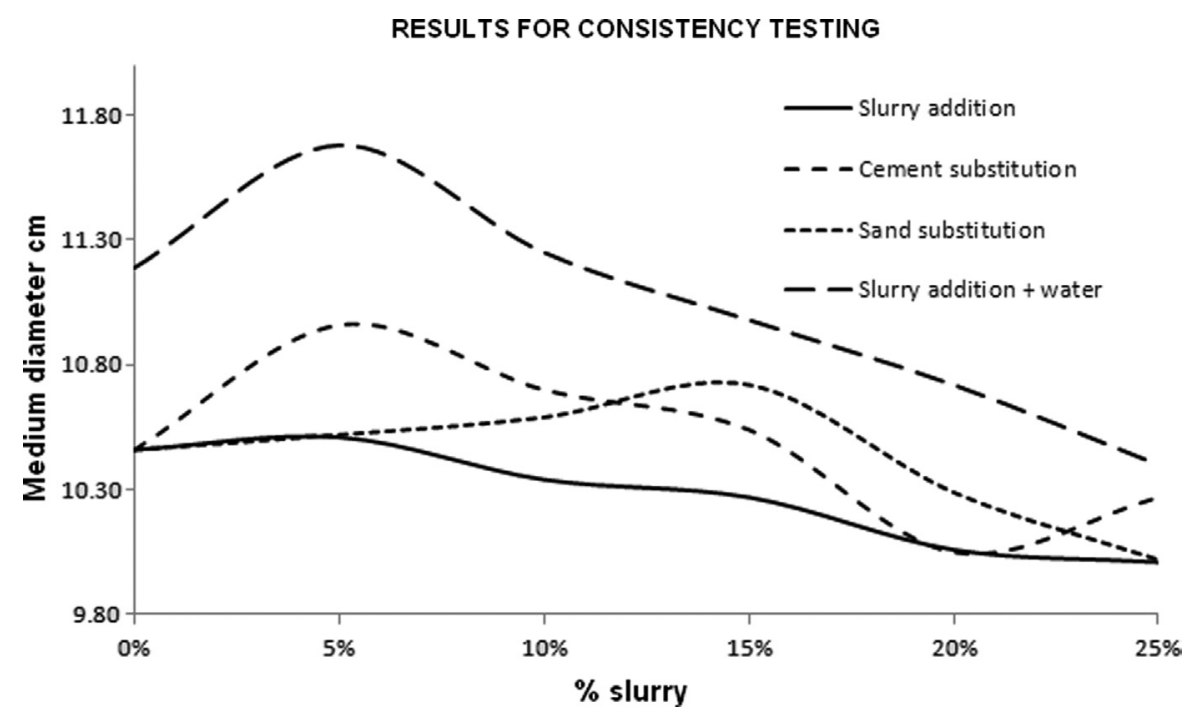

FIGURE 7. Results of the consistency tests. 
TABLE 4. Results of concrete samples testing

\begin{tabular}{lcccc}
\hline & $\begin{array}{c}\text { Water/ } \\
\text { cement } \\
\text { ratio }\end{array}$ & $\begin{array}{c}\text { Consistency } \\
\text { (cm) }\end{array}$ & $\begin{array}{c}\text { Compressive } \\
\text { strength } \\
\text { at 7 days } \\
\left(\mathbf{N} / \mathbf{m m}^{2}\right)\end{array}$ & $\begin{array}{c}\text { Compressive } \\
\text { strength } \\
\text { at 28 days } \\
\left(\mathbf{N} / \mathbf{m m}^{2}\right)\end{array}$ \\
\hline $\begin{array}{l}\text { Reference } \\
\text { sample }\end{array}$ & 0.79 & 8 & 29.8 & 34.1 \\
$10 \%$ slurry & 0.79 & 6 & 31.6 & 35.9 \\
$15 \%$ slurry & 0.81 & 8 & 28.7 & 33.1 \\
$20 \%$ slurry & 0.82 & 10 & 30.8 & 33.4 \\
\hline
\end{tabular}

\section{CONCLUSIONS}

The valuation and recycling of waste from exceeding concrete mixes and washing of mixing and transport machinery is possible and necessary. Besides, the use of these recycled products in new concrete mixes needs the study of characteristics variation for the correct implementation.

In this study, the most interesting results were obtained with the substitution of sand by dried slurry between 10 and $20 \%$ of cement weight. It corresponds to the substitution of the total water by wash water, with a maximum density of $1.2 \mathrm{~g} /$ $\mathrm{cm}^{3}$, and a proportional reduction of fines in the sand composition. It allows a much higher implementation than the one established in the recycling system studied, even higher than the one established in EHE-08 regulation, which limits this density to $1.1 \mathrm{~g} / \mathrm{cm}^{3}$

The results obtained with the only addition of dried slurry upto $5 \%$ were also interesting, which corresponds to the use of wash water with a maximum density of $1.08 \mathrm{~g} / \mathrm{cm}^{3}$.

This slurry cannot substitute cement. When the quantity of cement was reduced, all properties were affected.

The addition of slurry and water proportionally (with the reduction of water/cement ratio) also brought to the general reduction of the results in properties, although it was not so significant. This possibility can be considered whenever these worse results are taken into account.

Clear water seemed not to affect properties in new mixes, although the high alkalinity of this water was not analyzed, nor the possibility to react to other components.

The use of recovered aggregates in new concrete mixes requires the correction of its graduation, but any other problem is shown to the studied properties.

The obtained results are focused to the case in study. Notwithstanding, they can show new possibilities for recycling of wash water in new concrete mixes, with specific corrections in the mix. In a more complete study, more detailed results can be obtained in order to implement them in the whole industry of concrete production.

\section{ACKNOWLEDGEMENTS}

My acknowledgement is to Hormigones del Vinalopó S.L. and Frumecar S.L., for their collaboration in this research work. Special thanks to J. S. Alcaide Romero for his personal and professional support.

\section{REFERENCES}

1. Borger, J.; Carrasquillo, R.L.; Fowler, D.W. (1994) Use of recycled wash water and returned plastic concrete in the production of fresh concrete. Advanced Cement Based Materials, 1,267-274. http://dx.doi.org/10.1016/1065-7355(94)90035-3

2. Ministry of Public Works: (2008) Instrucción de Hormigón Estructural (EHE-08). BOE, 203, 1-304.

3. Sandrolini, F.; Franzoni, E.: (2001) Waste wash water recycling in ready-mixed concrete plants. Cem. Concr. Res. 31, 485-489. http://dx.doi.org/10.1016/S0008-8846(00)00468-3

4. Paolini, M.; Khurana, R.: (1998) Admixtures for recycling of waste concrete. Cem. Concr. Comp. 20, 221-229. http:// dx.doi.org/10.1016/S0958-9465(97)00066-8

5. Erdoğdu, S. (2005) Effect of retempering with superplasticizer admixtures on slump loss and compressive strength of concrete subjected to prolonged mixing. Cem. Concr. Res. 33, 907-912. http://dx.doi.org/10.1016/j.cemconres.2004.08.020

6. Su, N.; Miao, B.; Liu, F. (2002) Effect of wash water and underground water on properties of concrete. Cem Concr. Res. 32, 777-782. http://dx.doi.org/10.1016/S0008-8846(01)00762-1

7. Chatveera, B.; Lertwattanaruk, P.; Makul, N. (2006) Effect of sludge water from ready-mixed concrete plant on properties and durability of concrete. Cem. Concr. Comp. 28, 441-450. http://dx.doi.org/10.1016/j.cemconcomp.2006.01.001

8. UNE-EN 933-1:2012 (2012) Ensayos para determinar las propiedades geométricas de los áridos. Parte 1: Determinación de la granulometría de las partículas. Método del tamizado.

9. UNE-EN 933-8:2012 (2012) Ensayos para determinar las propiedades geométricas de los áridos. Parte 8: Evaluación de los finos. Ensayo del equivalente de arena.

10. Evangelista, L.; de Brito, J. (2010) Durability performance of concrete made with fine recycled concrete aggregates. Cem. Concr. Comp. 32, [1] 9-14. http://dx.doi.org/10.1016/ j.cemconcomp.2009.09.005

11. UNE-EN 196-1:2005 (2005) Métodos de ensayo de cementos. Parte 1: Determinación de resistencias mecánicas.

12. UNE-EN 1015-18:2003 (2003) Métodos de ensayo de los morteros para albañilería. Parte 18: Determinación del coeficiente de absorción de agua por capilaridad del mortero endurecido.

13. UNE-EN 1015-3:2000/A2:2007 (2007) Métodos de ensayo para morteros de albañilería. Parte 3: Determinación de la consistencia del mortero fresco (por la mesa de sacudidas).

14. UNE-EN 196-3:2005+A1:2009 (2009) Métodos de ensayo de cementos. Parte 3: Determinación del tiempo de fraguado y de la estabilidad de volumen.

15. UNE-EN 12350-2:2009 (2009) Ensayos de hormigón fresco. Parte 2: Ensayo de asentamiento.

16. UNE-EN 12390-3:2009/AC: (2011) Ensayos de hormigón endurecido. Part 3: Determinación de la resistencia a compresión de probetas.

17. Pereira, P.; Evangelista, L.; de Brito. J. (2012) The effect of superplasticizers on the mechanical performance of concrete made with fine recycled concrete aggregates. Cem. Concr. Comp. 34 [9], 1044-1052. http://dx.doi.org/ 10.1016/j.cemconcomp.2012.06.009

18. Katz, A. (2003) Properties of concrete made with recycled aggregate from partially hydrated old concrete. Cem. Concr. Res. 33, [5], 703-711. http://dx.doi.org/10.1016/ S0008-8846(02)01033-5

19. Leite, M.B. (2001) Evaluation of the mechanical properties of concrete made with recycled aggregates from construction and demolition waste (en portugués), p. 270, $\mathrm{PhD}$ Thesis, Federal University of Rio Grande do Sul, Porto Alegre (Brazil). 